\title{
Trust, Efficient Contracting and Export Upgrading
}

\author{
Gideon Ndubuisi $^{1,2} \cdot$ Solomon Owusu ${ }^{1,2}$
}

Accepted: 21 October 2021 / Published online: 15 November 2021

(c) The Author(s) 2021

\begin{abstract}
Informal contracting institutions constitute an essential part of a country's overall contracting institution, however, the nascent literature examining the effect of contracting institutions on the quality of products a country produces and exports, have paid a limited attention on the role of informal contracting institutions. We fill this gap in the literature by examining whether higher trust levels, as an informal contracting institution, leads to product-quality upgrading by reducing contractual frictions and opportunistic behaviors. Using industry-level data spanning 19952014, we examined this relationship using the generalized difference-in-difference method. We find that contract-intensive industries in trust-intensive societies experience a disproportionally higher increase in the production and export of higherquality products compared to those industries in low-trusting societies. This result holds after controlling for conventional sources of comparative advantage and formal contracting institution. Hence, the result underscores the importance of informal contracting institutions for improved economic performance and stress the crucial fact that countries with strong and efficient informal institutions can still benefit in market-related activities even in the presence of weak formal institutions.
\end{abstract}

Keywords Informal institution · Trust · Contractual frictions · Export quality

\section{Résumé}

Les institutions contractantes informelles constituent une partie essentielle du système contractant global d'un pays. Cependant, la littérature naissante qui étudie l'effet des institutions contractantes sur la qualité des produits qu'un pays fabrique et exporte, a accordé une attention limitée au rôle des institutions contractantes informelles. Nous comblons cette lacune dans la littérature en cherchant à savoir si des niveaux de confiance plus élevés, en tant qu'institution contractante informelle, conduisent à une

Gideon Ndubuisi

gideon.ndubuisi@die-gdi.de

Solomon Owusu

solomon.owusu@die-gdi.de

1 Deutsches Institut für Entwicklungspolitik, Bonn, Germany

2 UNU-MERIT/Maastricht University, Maastricht, The Netherlands

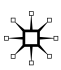


amélioration de la qualité des produits en réduisant les frictions contractuelles et les comportements opportunistes. À l'aide de données issues de l'industrie couvrant la période 1995-2014, nous avons examiné cette relation à l'aide de la méthode des doubles différences généralisées. Nous constatons que, dans les sociétés où le niveau de confiance est élevé, les industries qui générent de nombreux contrats connaissent une augmentation forte et disproportionnée de la production et de l'exportation de produits de qualité supérieure, par rapport à ces mêmes industries dans des sociétés où le niveau de confiance est faible. Ce résultat reste valable après avoir contrôlé les sources conventionnelles d'avantage comparatif et l'institution contractante formelle. Par conséquent, les résultats soulignent le rôle important que jouent les institutions contractuelles informelles dans l'amélioration de la performance économique. Ils mettent aussi l'accent sur un fait essentiel : les pays dotés d'institutions informelles solides et efficaces peuvent toujours bénéficier d'activités liées au marché, même lorsque les institutions formelles sont faibles.

JEL Classification D70 $\cdot$ F00 $\cdot$ F10 $\cdot$ F14

\section{Introduction}

A long-standing consensus in the literature suggests that differences in the quality of products produced and exported by countries play a significant role in explaining the variation in cross-country export success and overall economic performance. Importantly, products at the higher quality spectrum face less elastic demand, and they provide higher profit margins than more standardized and lower quality products (Hallak 2006; Hausmann et al. 2007; Khandelwal 2010; Amiti and Khandelwal 2013; Huchet-Bourdon et al. 2017; Papageorgious et al. 2019; Henn et al. 2020). Consequently, a large body of literature has emerged examining the drivers of the quality of products produced and exported with prior studies largely focusing on economic factors such as factor endowments, trade liberalization, foreign direct investment (FDI), income and preferences, innovative capability, technology transfer, and financial development (Mora 2002; Schott 2004; Faruq 2011; Harding and Javorcik 2012; Amiti and Khandelwal 2013; Zhu and Fu 2013; Crino and Ogliari 2017; Ndubuisi and Owusu 2021).

More recently, socioeconomic factors such as institutional quality are gaining traction in the literature (Faruq 2011; Essaji and Fujwara 2012; Falkowski et al. 2019). Notably, this literature argues that upgrading product quality often requires producers to source inputs or technologies outside a firm's boundary or collaborate with multiple parties. These make product quality upgrading a contract-intensive endeavor, as it requires producers entering into a contractual relationship with third parties, which exposes the production process to contractual frictions such as the classical holdup problem. In which case, product quality upgrading depends on the effectiveness of contracts governing the contractual relationship among implied parties. Until date, extant studies that examine this relationship have focused mainly on formal institutional quality (e.g., the rule of law, bureaucratic quality, and judicial 
quality), while ignoring the role of informal contracting institutions such as trust. This is surprising given that informal contracting institutions, such as trust, constitute an essential part of a country's overall contracting institution (Lyons and Mehta 1997; Knack and Keefer 1997; Mccannon et al. 2017; Gil and Zanarone 2017; Ndubuisi 2020a). The objective of the current paper is to fill this gap. In particular, we examine how trust, as an informal contracting institution, leads to improvements in product-quality by reducing contractual frictions.

Trust is the subjective probability that an economic agent assesses that others will perform a particular action (Gambetta 1988). Its importance as an informal mechanism of contract enforcement is well documented in the literature (Arrow 1970; Lyons and Mehta 1997; Knack and Keefer 1997; Bjørnskov and Méon 2015; Ang et al. 2015; Mccannon et al. 2017; Gil and Zanarone 2017; Ndubuisi 2020a). Arrow (1970), for instance, notes that in the absence of trust, it would become very costly to arrange for alternative sanctions and guarantees, and many opportunities deriving from mutually beneficial cooperation would have to be forgone (p. 70). Similarly, Lyons and Mehta (1997) argue that efficient exchange relations, especially where unobserved efforts are important, are facilitated when the parties trust each other. As argued further by the authors, this occurs because trust reduces specification and monitoring costs, encourages better investment decisions, and ensures rapid and flexible responses to unforeseen events. By the same token, we conjecture that a higher level of trust would lead to product quality upgrading because it encourages stable and much longer efficient contractual relationships with third parties, such as suppliers of sophisticated and customized inputs.

To empirically examine this conjecture, we utilize an industry-level data across 71 countries over the period spanning 1995-2014. As an empirical strategy, we employ the generalized difference-in-difference method developed by Rajan and Zingales (1998) and has been used extensively elsewhere in the literature (e.g., Levchenko 2007; Nunn 2007; Essaji and Fujiwara 2012; Manova 2013; Crino and Ogliari 2017; Ndubuisi 2020b). In particular, rather than asking whether trust-intensive societies produce and export higher quality products, our empirical strategy evaluates whether industries that are more prone to contractual frictions, such as the classical holdup problem, experience a disproportionately increase in the production and export of higher-quality products in trust-intensive societies than those industries in low-trusting societies. Utilizing this approach offers at least two gains. First, it minimizes concern over omitted variable bias as it allows the inclusion of different fixed effects at the country and industry level. Secondly, it allows us to focus on a specific mechanism, in our case, the reduction in contractual frictions, through which the examined variables are related.

As an empirical measure of an industry's vulnerability to contractual frictions, we use Nunn (2007)'s industry contract-intensity measure (2007). The index classifies products to the extent their production is prone to imperfect contract enforcement and, therefore, to the quality of contracting institutions. In which case, in the absence of trust (which is the focus of the current paper) and effective formal contracting institution (which has been the focus of extant studies), countries would suffer a comparative disadvantage in those industries. For the measure of trust, we follow the trust-related literature (e.g., Zak and Knack 2001; Pelvzner et al. 2008; Dearmon 
and Grier 2011; Ndubuisi 2020b), and use the trust indicator from the World Value Survey, measured as the proportion of a country's population that "agrees" with the statement, "Most people can be trusted". Finally, we rely on the novel method developed by Khandelwal et al. (2013) to infer product-quality from bilateral export data.

Previewing the empirical results, we find that trust-intensive societies have a comparative advantage in the production and export of higher quality products in industries that are more vulnerable to contractual frictions. This result persists after controlling for conventional sources of comparative advantage and formal contracting institutions. Hence, our result suggests that trust, as an integral part of a country's overall contracting institution, exerts a positive impact on product-quality upgrading independent of formal contracting institutions' quality. Among others, two potential channels/mechanism may index this effect. Firstly, trust as an informal enforcement mechanism substitutes formal enforcement mechanisms where they are either lacking or are weak. In which case, a country having weak formal contracting institutions may still specialize in producing and exporting higher quality products, provided the informal contracting institutions are strong. Secondly, trust as a complement to formal contracting institution leads to a more efficient formal contracting. Such could include promoting ex-ante negotiating efficiency by allowing greater flexibility to respond to changing market conditions because contracting parties have greater confidence in each party's information. It could also emerge from lowering the amount of time and resources contracting parties devote to ex-post bargaining and haggling over problems that arise in the course of exchange (Dyer and Chu 2003; Ndubuisi 2020a).

This paper contributes to different strands in the literature. First, it relates to nascent literature that considers the impact of culture on product upgrading (e.g., Faruq and Webb 2016; Fan et al. 2018). In particular, while Faruq and Webb (2016) studied the export quality effects of cultural diversity using the Hofstede's four original cultural dimensions (i.e., power distance, uncertainty avoidance, individualism, and masculinity), ${ }^{1}$ Fan et al. (2018) examined the export sophistication effects of cultural diversity using the cultural diversity index constructed by Ashraf and Galor (2011). We contribute to this literature in three ways: (a) using an inferred product-quality measure $^{2}$; (b) focusing on social trust (which is a contracting institution) instead of culture; and (c) focusing on a specific channel through which social trust affects product quality. Secondly, as product-quality upgrading is an important element of innovation, our study also contributes to the literature examining the nexus between trust and innovation, which tend to use either patent application counts (Akçomak and ter Weel 2009) or R and D intensity (Ndubuisi 2020b). In particular, our results suggest an innovation effect of social trust in the form of vertical upgrading. Finally, to the extent that product-quality determines export successes and economic growth, our study also contributes to the nascent literature on the trade effect of trust (e.g., Guiso et al. 2009; Ndubuisi 2020a) and the erstwhile literature on the development effect of trust (see Knack and Keefer 1997; Dearmon and Grier 2011).

\footnotetext{
1 Faruq (2016) measures quality using a fisher price index.

2 Export sophistical and prices criticized in the literature.
} 
The remainder of the paper is organized as follows. "Related Literature" section presents a related literature review, while "Research Method" section discusses the research methodology, specifying the empirical model and describing the different data sources used in the analysis. "Empirical Results" section presents the empirical results. "Conclusion" section concludes.

\section{Related Literature}

Studies investigating the drivers of product-quality upgrading have gained increasing traction in recent years. Underpinning this rise lies the gains associated with a country producing and exporting higher quality products. Particularly, it is now widely argued that producing and exporting higher quality and sophisticated products is associated with better economic performance, including economic growth and development, export success, and better labor market outcomes (Brooks 2006; Hausmann et al. 2007; Verhoogen 2008; Khandelwal 2010; Amiti and Khandelwal 2013; Crino and Ogliari 2017). Extant studies examining the drivers of export upgrading have predominantly focused on the role of economic factors such as trade liberalization, foreign direct investment (FDI), income and preferences, innovative capability, and financial development (Mora 2002; Schott 2004; Faruq 2011; Harding and Javoricik 2012; Amiti and Khandelwal 2013; Zhu and Fu 2013; Crino and Ogliari 2017; Ndubuisi and Owusu 2021; Owusu 2021).

Beginning with the factor-endowments, pioneer studies such as Acharyya and Jones (2001), Mora, (2002), Schott (2004), and Hummels and Klenow (2005) show that country characteristics such as income, preferences, and resource and capital endowments affect the quality of products. Regarding trade liberalization, existing studies suggest that it enhances the quality of exported products (Amiti and Khandelwal 2013; Fan et al. 2015; Bas and Strauss-Kahn 2015; Manova and Yu 2017). The export quality enhancing effects of trade liberalization can accrue in two ways. First, trade liberalization, say, in the form of input tariff liberalization provide domestic firms access to cheaper and higher-quality intermediate inputs needed for productivity improvement, which are important drivers of export upgrading. Second, trade liberalization can also affect export quality through a pro-competitive effect by lowering output tariffs, which raise product market competition and could force domestic firms to either lower their markups or revise their product quality (Bas and Strauss-Kahn 2015).

Similar to the trade liberalization literature, studies on the effect of FDI on export quality generally points to a positive relationship (Faruq 2011; Harding and Javorcik 2012; Zhu and Fu 2013; Anwar and Sun 2018). As noted by Harding and Javorcik (2012), FDI enhances the quality of exported products because it serves as an important conduit of technology transfers and spillovers to local firms, which tend to drive down the marginal cost of production and boost the innovative ability of local firms. Also, multinationals are usually exposed to better technology, possess superior production capabilities, and have access to cheaper sources of finance. The culmination of these makes it possible to produce higher quality goods than those previously produced and exported by the host country. Closely related to the FDI 
literature, studies on the nexus between product quality and credit access are rooted in the argument that product-upgrading is a cost-intensive endeavor. Along this line, access to quality and affordable credit enables domestic firms to upgrade the quality of their products. Indeed, Fan et al. (2015) note that limited access to finance causes firms to act in ways that would be suboptimal in normal times, which may lead them to produce lower-quality products. In general, available empirical evidence corroborates the important role of finance for product upgrading (Fan et al. 2015; Crino and Ogliari 2017; Ciani and Bartoli 2020).

Whereas the above studies focus mainly on economic factors, few studies have also analyzed the role of socioeconomic factors such as institutional quality (Faruq 2011; Essaji and Fujiwara 2012; Falkowski et al. 2019). The theoretical underpinning of these studies is based on the transaction cost theory wherein poor institutional quality proliferates uncertainties about the circumstances in which producers and final good producers could operate and collaborate to produce the optimal output. Along this line, Faruq (2011) empirically shows that malfunctioning social and political institutions can impair the ability of producers to improve the quality of their exported goods by discouraging innovation and investment. Essaji and Fujiwara (2012) and Falkowski et al. (2019) employ an augmented factor-proportion model and found that countries with a stronger rule of law or judicial system have a comparative advantage in exporting higher quality contract intensive final goods.

Whiles these few literature have provided crucial insights on the nexus between institutions and export quality, they have focused mainly on formal institutional quality. The role of informal contracting institutions in this relationship is largely ignored. This is surprising given that informal contracting institutions, such as trust, constitute an essential part of a country's overall contracting institution (Arrow 1970; knack and Keefer 1997; Bjørnskov and Méon 2015; Mccannon et al. 2017). We fill this gap in the literature by examining whether higher trust levels, as an informal contracting institution, leads to product-quality upgrading by reducing contractual frictions and opportunistic behaviors.

Along these lines, our paper relates closely to the nascent literature that considers the impact of culture on product upgrading (e.g., Faruq and Webb 2016; Fan et al. 2018). Utilizing export prices as a quality measure, Faruq and Webb (2016) studied the export quality effects of cultural diversity using Hofstede's four original cultural dimensions (i.e., power distance, uncertainty avoidance, individualism, and masculinity). On the other hand, Fan et al. (2018) examined the export sophistication effects of cultural diversity using the cultural diversity index constructed by Ashraf and Galor (2011). We make three notable innovations in this literature including (a) using an inferred product-quality measure as opposed to export prices or export sophistication as used in the two studies ${ }^{3}$; (b) focusing on social trust (which is a

\footnotetext{
3 The use of prices as quality has been hugely criticized in the literature on many grounds. For example, Hallak and Schott (2011) argue that rather than differences in product-quality, prices of exported products may vary because firms can sell at a discount due to lower production costs or undervalued exchange rates. Also, Amiti and Khandelwal (2013) note that unit prices may be inappropriate measures for quality when products possess both vertical and horizontal attributes since differences in unit values of a similar product from different countries at different development levels may capture in part wage differentials. For criticism on using export sophistication as a quality measure see Minondo (2010).
} 
contracting institution) instead of culture; and (c) focusing on a specific channel through which social trust affects product quality. The latter has the added advantage of focusing on a potential mechanism through which the explanatory variable of interest affects the outcome variable, thereby enabling us to overcome potential endogeneity issues.

\section{Research Method}

\section{Empirical Strategy}

Our empirical strategy relates product-quality to country-industry interaction to investigate whether higher levels of trust leads to product-quality upgrading. It builds on Rajan and Zingales (1998) seminal work. In that study the authors interact industry variable (financial dependence) with a country-specific measure of financial development to study the differential output growth effects of financial development. To this end, the empirical model that guides our analysis takes the form:

$$
\text { Quality }_{i, j, t}=\delta_{0}+\delta_{1} \text { trust }_{i, t}+\delta_{2}\left(\text { trust }_{i, t} \times \text { contract intensity }_{s}\right)+\gamma X^{\prime}+\tau_{t}+\tau_{i}+\tau_{s}+\tau_{j}+\mu_{i, s, j, t}
$$

where Quality $_{i, j, t}$ is the quality of product $j, i$ denotes a country, while $t$ is the year index. $s$ denotes industry, and $\mu_{i, j, t}$ describes the error term. $\tau_{t}$ is year dummies, while $\tau_{i}, \tau_{s}$ and $\tau_{j}$ are country, industry and product fixed effects, respectively. trust $_{i, t}$ is a country-specific measure of the level of trust. Contract intensity is an industryspecific measure of contractual friction vulnerability. That is, it captures the relative importance of contracting to an industry. The index is both country and time-invariant. Hence, we exclude its direct measure from the equation since the industry fixed effects would capture it. In line with our research objective, $\delta_{2}$ is the coefficient of interest, and we expect it to be positive and statistically significant. However, the total effect of trust on product-quality is captured by $\frac{\partial\left(\text { Quality }_{i, j}\right)}{\partial\left(\text { trust }_{i, t}\right)}=\delta_{1}+\delta_{2}$ contract intensity $_{s}$, while the variance of the total effect is given by $\operatorname{Var}\left(\delta_{1}\right)+$ Contract Intensity ${ }_{s}^{2} \times \operatorname{Var}\left(\delta_{2}\right)+2$ contract intensity ${ }_{s} \times \operatorname{Cov}\left(\delta_{1} \delta_{2}\right)$. Finally, $X^{\prime}$ is a vector of control variables. We follow studies that utilize a similar empirical framework as ours (e.g., Nunn 2007; Essaji and Fujwara 2012; Manova 2013; Ndubuisi 2020a) and include standard country-industry measures of comparative advantage. This includes an interaction variable between industry skill-intensity and country endowment of skilled-labor and an interaction variable between industry capital-intensity and country endowment of physical capital. ${ }^{4}$

\footnotetext{
4 Data on countries' human and physical capital are from the Penn World Table (PWT), while data on industry factor intensities are from Manova (2013).
} 


\section{Data Sources}

\section{Product Quality Measure}

Comparable cross-country data on domestic products are hardly available. Hence, a common approach in the literature is to use data on exported products. While our empirical analysis follows this approach, another empirical challenge is that tradable products' quality is unobserved. While the conventional approach has been to use prices as an empirical measure on the assumption that price equals quality, this approach has come under large criticisms. Recently, Khandelwal et al. (2013) developed a novel method to infer quality indirectly from observed prices and demands given an explicit functional form. ${ }^{5}$ Particularly, it infers product quality as unobserved attributes of a variety that make consumers willing to purchase relatively large quantities of the variety despite relatively high prices charged for the variety. In which case, the intuition behind the approach is that conditional on price, a variety with a higher quantity is assigned higher quality. Hence, following Khandelwal et al. (2013), we infer the quality of product $j$ shipped to a destination country $d$ by country $i$ in year $t$, using the following empirical demand equation based on Eq. (2):

$$
k_{i, j, d, t}=\left(q_{i, j, d, t}\right)^{\sigma-1}\left(p_{i, j, d, t}\right)^{-\sigma}\left(P_{d, t}\right)^{\sigma-1}\left(Y_{d, t}\right)
$$

where $k_{i, j, d, t}$ is the quantity of product $j$ produced by country $i$ and exported to destination country $d$ in year $t, p_{i, j, d, t}$ and $q_{i, j, d, t}$ is the price and the quality of the exported product. $P_{d, t}$ and $Y_{d, t}$ is the price index and income level of the destination country, while $\sigma$ is the elasticity of substitution. We take logs of the demand equation and arrive at Eq. (3) which we would estimate using OLS:

$$
\ln \left(k_{i, j, d, t}\right)+\sigma \ln \left(p_{i, j, d, t}\right)=\tau_{d, t}+\tau_{j}+\psi_{i, j, d, t}
$$

where the destination country time-varying fixed effect $\tau_{d, t}$ absorbs both $P_{d, t}$ and $Y_{d, t}$, $\tau_{j}$ denotes product fixed effects which control for variation across products, such as the difference in prices and quantities across product categories due to the inherent characteristics of products. $\psi_{i, j, d, t}$ is the error term. The inferred quality estimate is, then, given by the estimated residual of Eq. (3) as:

$$
\widehat{q}_{i, j d, t}=\widehat{\psi}_{i, j, d, t} /(\sigma-1)
$$

Following Manova and Yu (2017), we set the elasticity of substitution across products at the commonly used value of 5. To infer the product quality, we utilize the BACI-CEPII dataset (Gaulier and Zignago 2010), which contains bilateral export values and quantities at the 6-digit Harmonized System Classification (HSC) for a large number of countries. We define a product as a 6-digit HSC, while a product price is the product's unit price (i.e., value divided by quantity). Accordingly, we

\footnotetext{
5 For studies that have employed similar approach see Fan et al. (2015), Manova and Yu (2017), Falkowski et al. (2019) and Ndubuisi and Owusu (2021).
} 
take three steps to arrive at the final quality measure we use in the empirical analysis. First, we utilize the bilateral export data to compute the quality estimate following the steps outline in Eqs. (3) and (4). Second, we construct a country-product specific measure of quality by averaging across the importing countries. Hence, the quality index is not destination-specific. Third, we map these products to the corresponding 3-digit International System Industry Classification using an appropriate correspondence table. ${ }^{6}$

\section{Trust Measure}

Trust can be broadly classified into two: "particularized trust" and "generalized trust". While particularized trust refers to the preconception an agent or group of an agent have on a "known" agent or group of agents, generalized trust refers to the preconception an agent or a group of an agent have on others unknown. As noted by Bottazzi et al. (2016), while particularized trust focuses on a specific trading partner, generalized trust concerns more broadly, the "institutions" that govern transactions in the partner's country. As the focus of our study is on how informal contracting institution incentives economic agents to enter into stable and much longer efficient contractual relationships with [unknown] third parties, such as suppliers of sophisticated and customized inputs that may be unknown to each other into stable and relationship, we focus on generalized trust. The importance of such type of trust in business contracting is well-established in the literature. Bjørnskov and Méon (2015) noted that it reflects the average trustworthiness of people and the likelihood that they abide by both formal rules and informal social contracts. To measure this variable, we rely on the perception-based trust indicator from the WVS following the large body of literature on trust (e.g., Zak and Knack 2001; Bjørnskov 2007; Pevzner et al. 2015; Bottazzi et al. 2016; Ndubuisi 2020a). The variable is measured as the proportion of a country's population that "agrees" with the statement, "Most people can be trusted". A score of 1 is then the highest level of trust in the country. While the original data on trust are occasionally available, Castellacci and Natera (2011) used different imputation methods to generate a time series for many countries. ${ }^{7}$ While the data provided by the authors ends in 2008, Osei (2019) extended the time series of the data to 2014 following the approach in Castellacci and Natera (2011). Our analysis uses the extended version of the data provided by Osei (2019). ${ }^{8}$

\section{Contract Intensity}

Our primary measure of industry vulnerability to contractual frictions is the "contract-intensity" index developed by Nunn (2007). The index measures each industry's susceptibility to a specific type of contractual friction resulting from final

\footnotetext{
6 The correspondence table is taken from here https://wits.worldbank.org/product_concordance.html.

7 Castellacci and Natera (2011) use imputation methods to fill-in missing observations for different countries. We kindly refer the reader to the article for a more detailed description of the data.

8 We are most grateful to the author for sharing the data.
} 
goods producers entering into relationship-specific investment. To compute the index, Nunn combined the 1997 US Input-Output Use Table with Rauch's (1999) classification of internationally traded goods to identify the types and shares of intermediate inputs used in each production final good, which is then aggregated to the industry level. While the Input-Output Use Table provides information on the share of intermediate inputs used to produce a final good, Rauch (1999) classifies internationally traded goods into three: those traded on organized exchanges, those not traded on organized exchanges but are reference priced in trade publications, and all other commodities. Nunn argued that products that are neither reference priced in trade publications nor traded on an organized exchange are not traded in open markets. Hence, they require producers to make relationship-specific investments, which are prone to holdup problems. That is, the input supplier may either halt or threaten to halt its supply at any time, thereby requiring the producer to write a contract with the input supplier. Accordingly, he constructs the contract-intensity index, as the share of intermediate inputs not traded on the open market required to produce each final goods in the industry.

Arguing that inputs that are not sold on an organized exchange but are reference priced in trade publications have an intermediate level of relationship specificity since trade publications are produced only when there is a sufficient number of purchasers of the publication, Nunn developed a second contract-intensity index. The index is computed as the share of intermediate goods not sold on the open market and those that are reference priced in trade publications that are required for production in each industry. Since we are interested in contractual frictions in the least possible ways, we use the second index in the analysis. Nonetheless, we show results using the first measure in the robustness section. We also test the robustness of our results using the Herfindahl index of intermediate input use. Data on the index are taken from Cowan and Neut (2007). The index is built with the idea that the more variety of inputs are used, the more complex the production of a final good is and the more sensitive to contracting institutions' quality. Following Levchenko (2007), we multiply the index by -1 so that the index would be interpreted similarly as the Nunn contract-intensity index. Table A2 in the Online Appendix reports the industry characteristics used in the analysis.

\section{Empirical Results}

\section{Main Results and Robustness Checks}

Table 1 shows the baseline regression results. Column 1 reports the results when we only regress the outcome variable on trust and the interaction variable between trust and contract-intensity while conditioning on country, industry, and year fixed effects. The interaction variable is significantly positive at all conventional significance levels, indicating that contract-intensive industries in trust-abundant societies experience a disproportionally higher increase in the production and export of higher-quality products than those in low-trusting societies. In particular, based on the magnitude of the estimated coefficient of the interaction variable, the result 
Table 1 Main results: trust and product quality upgrading

\begin{tabular}{|c|c|c|c|c|c|c|}
\hline & (1) & (2) & (3) & (4) & (5) & (6) \\
\hline \multirow[t]{2}{*}{ Trust } & $-0.8270 * * *$ & $-0.6702 * * *$ & & $-0.6699 * * *$ & & $-0.7510 * * *$ \\
\hline & {$[0.028]$} & {$[0.028]$} & & {$[0.028]$} & & {$[0.018]$} \\
\hline \multirow{2}{*}{$\begin{array}{l}\text { Trust } \times \text { Contract } \\
\text { intensity }\end{array}$} & $1.0534 * * *$ & $0.8736^{* * *}$ & $0.8689 * * *$ & $0.8728 * * *$ & $0.8673 * * *$ & $0.9626^{* * *}$ \\
\hline & {$[0.026]$} & {$[0.026]$} & {$[0.026]$} & {$[0.026]$} & {$[0.026]$} & {$[0.017]$} \\
\hline \multirow[t]{2}{*}{ Human capital } & & $-0.5653 * * *$ & & $-0.5085^{* * *}$ & & $-0.5263 * * *$ \\
\hline & & {$[0.013]$} & & [0.013] & & [0.009] \\
\hline \multirow{2}{*}{$\begin{array}{l}\text { Human capi- } \\
\text { tal } \times \text { Skill } \\
\text { intensity }\end{array}$} & & $0.0604 * * *$ & $0.0599 * * *$ & $0.0554 * * *$ & $0.0551 * * *$ & $0.0604 * * *$ \\
\hline & & {$[0.001]$} & {$[0.001]$} & {$[0.001]$} & {$[0.001]$} & {$[0.001]$} \\
\hline \multirow[t]{2}{*}{ Physical capital } & & $-0.0524 * * *$ & & $-0.0442 * * *$ & & $-0.0214 * * *$ \\
\hline & & {$[0.004]$} & & {$[0.004]$} & & {$[0.003]$} \\
\hline \multirow{2}{*}{$\begin{array}{l}\text { Physical capi- } \\
\text { tal } \times \text { Capital } \\
\text { intensity }\end{array}$} & & $0.1928 * * *$ & $0.1907 * * *$ & $0.1664 * * *$ & $0.1660 * * *$ & $0.2119 * * *$ \\
\hline & & {$[0.010]$} & {$[0.010]$} & {$[0.010]$} & {$[0.010]$} & {$[0.008]$} \\
\hline Product dummies & No & No & No & No & No & Yes \\
\hline Sector dummies & Yes & Yes & Yes & No & No & No \\
\hline $\begin{array}{l}\text { Sector-year dum- } \\
\text { mies }\end{array}$ & No & No & No & Yes & Yes & No \\
\hline Country dummies & Yes & Yes & No & Yes & No & Yes \\
\hline $\begin{array}{l}\text { Country-year dum- } \\
\text { mies }\end{array}$ & No & No & Yes & No & Yes & No \\
\hline Year dummies & Yes & Yes & No & No & No & No \\
\hline \# observations & $4,307,606$ & $4,307,606$ & $4,307,606$ & $4,307,606$ & $4,307,606$ & $4,307,606$ \\
\hline$R^{2}$ & 0.35 & 0.35 & 0.36 & 0.35 & 0.36 & 0.64 \\
\hline
\end{tabular}

Robust standard errors in square brackets

$* * * p<0.01, * * p<0.05, * p<0.10$

suggests that for an industry with an average contract-intensity $(0.865)$, the average product quality would increase by $18.3 \%(=0.865 \times 1.0534 \times 0.201)$ in a country with trust level at the 75 th percentile $(0.392)$ compared to a country with a trust level at the 25th percentile (0.191). Hence, the result supports our conjecture about the pivotal role higher levels of trust play in contracting, especially regarding reducing contractual friction. From an econometrics point of view, when the interaction term is included in the estimation, the estimate on trust is interpreted as the effect of trust on export quality where contractual friction is zero. However, as can be seen in Table AII in the Online Appendix, the values of industry contract intensity is always greater than zero. Hence, although the coefficient of trust is statistically significant, it is not economically meaningful.

Next, column 2 shows the result when we include variables on conventional sources of comparative advantage. Introducing these variables reduces the size of 
the interaction variable's estimated coefficient between trust and industry contract intensity from 1.0534 in column 1 to 0.8736 , indicating that our model suffers from severe omitted variable bias without including them. Nonetheless, the variable remained significantly positive at the $1 \%$ significance level. In terms of economic significance, the interaction variable's estimated coefficient between trust and contract-intensity reported in column 2 suggests that a one standard deviation improvement in trust level would increase the average product quality in an industry with an average contract intensity of 0.875 by 10.6 percentage point. The average product quality across industries is -0.34 percentage points in the sample, while the maximum average product quality is 11.39 percentage points. Therefore, the 10.6 percentage point increase is substantial in economic terms. Table 2 reports the total effect of trust on export upgrading for each of the sectors in our sample using the estimations reported in column 2 of Table 1 . As we can see the total effect of trust on export upgrading varies across sector and is negative at lower levels of contract intensity, but significantly positive at higher levels of contract intensity. This reinforces the role of trust at higher levels of contractual friction, whiles it may have a detrimental effect when there are little or no contractual frictions.

Regarding the control variables, they show results that are consistent with a priori expectations. In particular, the estimated coefficient of the interaction variable between physical capital and capital-intensity is significantly positive, indicating that capital-endowed countries tend to specialize in the production and export of higherquality products in capital-intensive industries. Similarly, the interaction variable's significant positive estimated coefficient between human capital and skill-intensity suggests that skilled-labor endowed countries specialize in producing and exporting higher-quality goods in skilled-intensive industries. These results are also consistent with those reported in Crino and Ogliari (2017) and Falkowski et al. (2019). ${ }^{9}$

Next, columns 3 to 5 present additional baseline results using more stringent fixed effects to minimize potential omitted variable bias. In particular, column 3 shows the results when we include the time-varying country dummies, to minimize bias that may result from omitted time-varying country characteristics. Column 4 shows the result when we include time-varying industry dummies, while column 5 shows the result when we use time-varying industry dummies. In the three columns, the initial result suggesting that contract-intensive industries are better off in trustintensive society is preserved. This indicates that our previous result reported in column 2 is not driven by any omitted time-varying country, industry, and/or product characteristics.

In Tables A4 and A5 in the Online Appendix, we further conduct and report additional robustness checks on the baseline results. In particular, Table A4 in Online Appendix shows the results when we use Nunn (2007) first measure of

\footnotetext{
9 As in the case of contract intensity, note that in column 2 of Table 1, the linear terms of physical (human) capital that is negative is the effect of physical (human) capital for industries with zero capital (skill) intensity. However, as can be observe in Table AII in the Online Appendix, the values of capital and skill-intensity are always greater than zero, suggesting that the linear term variables though statistically significant does not make economic sense. Hence, our interpretation focuses only on the interaction variables.
} 


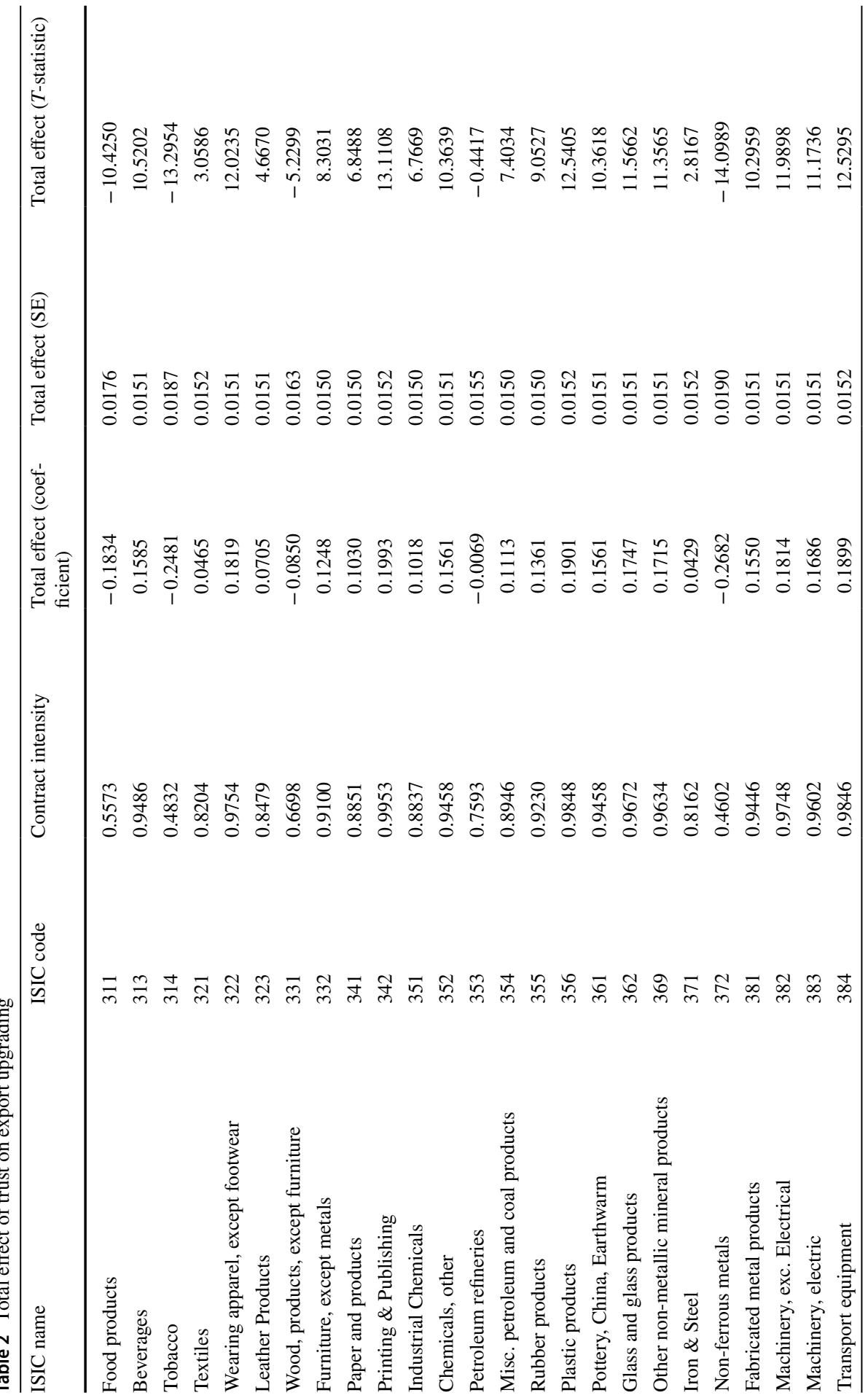

站。 


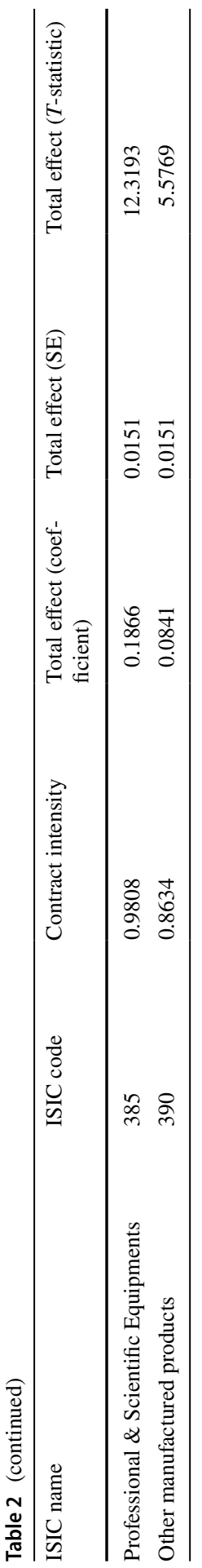


contract-intensity, while Table A5 in Online Appendix shows the results when we use the Herfindahl index of intermediate input. As discussed in "Contract Intensity" section, we use both indexes as alternative proxies for an industry's susceptibility to contractual frictions. In both columns, the results are consistent with those reported in Table 1, indicating that our prior results do not depend on how we measure industry susceptibility to contractual friction. Finally, extant studies that adopt the generalized difference-in-difference approach differ in how they model the serial correlation, ultimately influencing the standard errors. For instance, Rajan and Zingales (1998) report robust standard errors, while Seitz and Watzinger (2017) and Igan et al. (2016) report standard errors clustered at the country-level and country-industry level, respectively. To ensure our results are not driven by how we modeled the serial correlation, Table A6 in the Online Appendix shows the results using different standard errors. Columns 1 and 2 show the results when we use standard errors clustered at the country level, while columns 3 and 4 show the results when we use standard errors clustered at the country-industry level. In column 5 and 6, we cluster at the industry level. In all cases, the baseline result on the interaction variable between trust and contract-intensity is preserved.

\section{Additional Results}

This section provides additional results to show the robustness of the baseline results. While this paper's focus is on trust, which is an informal contracting institution, it can either substitute or complement formal contracting institutions (Mccannon et al. 2017; Ndubuisi 2020a). It could also be that trust only strengthens formal contracting institutions. Bjornsko and Meon (2015), for instance, find that trust affects total factor productivity through economic-judicial institutions. If the latter is the case, trust should not significantly affect the product quality of contract-intensive industries once we directly account for the differential effect of formal contracting institutional quality. We address this concern in column 1 of Table 3 by including an interaction variable between industry contract-intensity and country-specific measure of a formal contracting institution, as measured by the interaction variable between contract-intensity and "Law \& Order". Although introducing this variable reduces the number of observations and the size of the interaction variable's estimated coefficient between trust and industry contract-intensity, the interaction variable between trust and industry contract-intensity remained positive and statistically significant at the $1 \%$. Interestingly, the estimated coefficient of the interaction variable between formal contracting institution and industry contract-intensity is also significantly positive, confirming results in the extant literature (Essaji and Fujiwara 2012; Falkowski et al. 2019). Therefore, the significant positive estimated coefficient of the interaction variable between trust and contract-intensity suggests that trust, as an informal contracting institution, influences the contract-intensive industries over and above those of formal contracting institutions. In which case, it is consistent with studies suggesting that trust plays a role in contracting independent of the level of formal contract mechanism (Knack and Keefer 1997; Bjørnskov and Méon 2015; Ang et al. 2015; Ndubuisi 2020a). 
Table 3 Trust and product quality: robustness results

\begin{tabular}{|c|c|c|c|c|c|}
\hline & (1) & (2) & (3) & (4) & (5) \\
\hline Trust & $\begin{array}{l}-0.0017 \\
{[0.033]}\end{array}$ & $\begin{array}{l}-0.3327 * * * \\
{[0.031]}\end{array}$ & $\begin{array}{l}-0.3901 * * * \\
{[0.030]}\end{array}$ & $\begin{array}{l}-0.5189 * * * \\
{[0.028]}\end{array}$ & $\begin{array}{l}-0.2915^{* * *} \\
{[0.030]}\end{array}$ \\
\hline Trust $\times$ Contract intensity & $\begin{array}{l}0.0675^{* *} \\
{[0.033]}\end{array}$ & $\begin{array}{l}0.4138 * * * \\
{[0.030]}\end{array}$ & $\begin{array}{l}0.5541 * * * \\
{[0.029]}\end{array}$ & $\begin{array}{l}0.7004 * * * \\
{[0.027]}\end{array}$ & $\begin{array}{l}0.3623 * * * \\
{[0.029]}\end{array}$ \\
\hline Human capital & $\begin{array}{l}-0.6174 * * * \\
{[0.013]}\end{array}$ & $\begin{array}{l}-0.6357 * * * \\
{[0.013]}\end{array}$ & $\begin{array}{l}-0.6511 * * * \\
{[0.013]}\end{array}$ & $\begin{array}{l}-0.5550 * * * \\
{[0.013]}\end{array}$ & $\begin{array}{l}-0.5383^{* * * *} \\
{[0.013]}\end{array}$ \\
\hline Human capita $\times$ Skill intensity & $\begin{array}{l}0.0646 * * * \\
{[0.001]}\end{array}$ & $\begin{array}{l}0.0589 * * * \\
{[0.001]}\end{array}$ & $\begin{array}{l}0.0526 * * * \\
{[0.001]}\end{array}$ & $\begin{array}{l}0.0595 * * * \\
{[0.001]}\end{array}$ & $\begin{array}{l}0.0525 * * * \\
{[0.001]}\end{array}$ \\
\hline Physical capital & $\begin{array}{l}-0.0078^{* *} \\
{[0.004]}\end{array}$ & $\begin{array}{l}-0.0171 * * * \\
{[0.004]}\end{array}$ & $\begin{array}{l}-0.0532 * * * \\
{[0.004]}\end{array}$ & $\begin{array}{l}-0.1205^{* * * *} \\
{[0.005]}\end{array}$ & $\begin{array}{l}-0.2210^{* * * *} \\
{[0.004]}\end{array}$ \\
\hline $\begin{array}{l}\text { Physical capital } \times \text { Capital } \\
\text { intensity }\end{array}$ & $\begin{array}{l}0.1455^{* * *} \\
{[0.011]}\end{array}$ & $\begin{array}{l}0.1965 * * * \\
{[0.011]}\end{array}$ & $\begin{array}{l}0.1984 * * * \\
{[0.010]}\end{array}$ & $\begin{array}{l}0.2573 * * * \\
{[0.010]}\end{array}$ & $\begin{array}{l}0.2174 * * * \\
{[0.010]}\end{array}$ \\
\hline Law \& Order & $\begin{array}{l}-0.1328 * * * \\
{[0.003]}\end{array}$ & & & & \\
\hline $\begin{array}{l}\text { Law \& Order } \times \text { Contract } \\
\text { intensity }\end{array}$ & $\begin{array}{l}0.1482 * * * \\
{[0.004]}\end{array}$ & & & & \\
\hline Log private credit & & $\begin{array}{l}-0.0948 * * * \\
{[0.005]}\end{array}$ & & & \\
\hline $\begin{array}{l}\text { Log private credit } \times \text { Contract } \\
\text { intensity }\end{array}$ & & $\begin{array}{l}0.1657 * * * \\
{[0.006]}\end{array}$ & & & \\
\hline $\begin{array}{l}\text { Human capital } \times \text { Contract } \\
\text { intensity }\end{array}$ & & & $\begin{array}{l}0.2007 * * * \\
{[0.008]}\end{array}$ & & \\
\hline $\begin{array}{l}\text { Physical capital } \times \text { Capital } \\
\text { intensity }\end{array}$ & & & & $\begin{array}{l}0.0725 * * * \\
{[0.003]}\end{array}$ & \\
\hline Log GDP pc & & & & & $\begin{array}{l}0.2530 * * * \\
{[0.007]}\end{array}$ \\
\hline $\begin{array}{l}\text { Log GDP pc } \times \text { Contract } \\
\text { intensity }\end{array}$ & & & & & $\begin{array}{l}0.1786^{* * * *} \\
{[0.005]}\end{array}$ \\
\hline Sector dummies & Yes & Yes & Yes & Yes & Yes \\
\hline Country dummies & Yes & Yes & Yes & Yes & Yes \\
\hline Year dummies & Yes & Yes & Yes & Yes & Yes \\
\hline \# Observations & $3,859,816$ & $3,836,614$ & $4,307,606$ & $4,307,606$ & $4,307,606$ \\
\hline$R^{2}$ & 0.36 & 0.35 & 0.35 & 0.35 & 0.35 \\
\hline
\end{tabular}

Robust standard errors in square brackets

$* * * p<0.01, * * p<0.05, * p<0.10$ 
Besides formal institutions, studies have found that the trust level may be correlated with other country characteristics such as a country's level of development, financial development, and human capital (Guiso et al. 2004; Dearmon and Grier 2011; Bjørnskov 2012). If these country characteristics were also a source of comparative advantage in contract-intensive industries, then our baseline results would be spurious. We address this concern by introducing an interaction variable between industry contract-intensity and different country characteristics. The results are reported in columns 2 to 4 of Table 3. Column 2 shows the results when we interact industry contract-intensity with a country-specific measure of financial development. Column 3 reports the interaction variable results between capital and contract intensive, while column 4 shows the result for the interaction with human capital. Finally, column 5 shows the result for the interaction of industry contract-intensity and country-specific GDP per capita. In the four columns, we continue to observe that contract-intensive industries in trust-intensive societies experience a disproportionally higher increase in the production and export of higher-quality products compared to those industries in a low-trusting society. Hence, the results reported in Table 3 support our conjecture of a positive effect of trust on product-quality upgrading, by reducing contractual frictions and opportunistic behaviors.

\section{Extended Analysis: High-Tech Industries and Quality Upgrading}

High-tech firms engage in the production of complex goods, requiring specialized knowledge outside the firm's boundary. This requires that firms share specialist knowledge, which is strictly confidential because they offer competitive advantages (Jong and Woolthuis 2008). Akin to this, high levels of uncertainties associated with the production of complex goods also imply that many issues and unforeseen circumstances need to be managed during the relationship, leading to underinvestment in those industries under a poor contracting environment. Even where formal contracting institution is strong, they may be expensive, lengthy, and insufficient in accounting for such contingencies that are rather a norm than the exception in hightech business relations. On the other hand, as higher levels of social trust leads to more efficient contracting, it is also possible that high-tech industries in trust-intensive societies would experience a higher increase in the production and export of higher quality goods due to the trust-induced contracting efficiency gains.

Against this backdrop, this section extends our analysis by examining whether social trust affects high-tech industries' product quality. As is common in the literature (e.g., Hsu et al. 2014), we proxy the industry's technology sophistication using R\&D intensity, which we retrieve from Kroszner et al. (2007). Table 4 reports the results. In particular, it replicates Table 1, but this time focuses on the interaction variable between trust and industry R\&D-intensity (as a proxy of industry technology sophistication). Consistent with our expectation, the interaction variable's estimated coefficient between trust and industry R\&D-intensity is significantly positive at all conventional significance levels in all the columns in the table. In general, the result is consistent with the argument that a higher level of trust enhances business contracting, which is somewhat consistent with those in Ang et al. (2015). 
Table 4 Trust and high-tech industry's product quality

\begin{tabular}{|c|c|c|c|c|c|c|}
\hline & (1) & (2) & (3) & (4) & (5) & (6) \\
\hline \multirow[t]{2}{*}{ Trust } & $-0.0329 * *$ & 0.0176 & & 0.0129 & & 0.0026 \\
\hline & {$[0.015]$} & {$[0.015]$} & & {$[0.015]$} & & {$[0.011]$} \\
\hline \multirow{2}{*}{$\begin{array}{c}\text { Trust } \times \text { R\&D } \\
\text { intensity }\end{array}$} & $5.8452 * * *$ & $3.5041^{* * *}$ & $3.5762 * * *$ & $3.6991 * * *$ & $3.7701 * * *$ & $4.0625^{* * *}$ \\
\hline & {$[0.144]$} & {$[0.148]$} & {$[0.148]$} & {$[0.148]$} & {$[0.148]$} & [0.109] \\
\hline Human capital & & $\begin{array}{l}-0.5606^{* * *} \\
{[0.013]}\end{array}$ & & $\begin{array}{l}-0.5001 * * * \\
{[0.013]}\end{array}$ & & $\begin{array}{l}-0.5170 * * * \\
{[0.009]}\end{array}$ \\
\hline \multirow[t]{2}{*}{$\begin{array}{l}\text { Human capital } \times \text { Skill } \\
\text { intensity }\end{array}$} & & $0.0600 * * *$ & $0.0594 * * *$ & $0.0547 * * *$ & $0.0543 * * *$ & $0.0597 * * *$ \\
\hline & & {$[0.001]$} & {$[0.001]$} & {$[0.001]$} & {$[0.001]$} & {$[0.001]$} \\
\hline Physical capital & & $\begin{array}{l}-0.0509^{* * *} \\
{[0.004]}\end{array}$ & & $\begin{array}{l}-0.0427^{* * * *} \\
{[0.004]}\end{array}$ & & $\begin{array}{l}-0.0197 * * * \\
{[0.003]}\end{array}$ \\
\hline \multirow{2}{*}{$\begin{array}{l}\text { Physical capi- } \\
\text { tal } \times \text { Capital } \\
\text { intensity }\end{array}$} & & $0.1690^{* * *}$ & $0.1669 * * *$ & $0.1422 * * *$ & $0.1418 * * *$ & $0.1859 * * *$ \\
\hline & & {$[0.010]$} & {$[0.010]$} & {$[0.010]$} & {$[0.010]$} & {$[0.008]$} \\
\hline Product dummies & No & No & No & No & No & Yes \\
\hline Sector dummies & Yes & Yes & Yes & No & No & No \\
\hline Sector-year dummies & No & No & No & Yes & Yes & No \\
\hline Country dummies & Yes & Yes & No & Yes & No & Yes \\
\hline $\begin{array}{l}\text { Country-year dum- } \\
\text { mies }\end{array}$ & No & No & Yes & No & Yes & No \\
\hline Year dummies & Yes & Yes & No & No & No & No \\
\hline \# Observations & $4,307,606$ & $4,307,606$ & $4,307,606$ & $4,307,606$ & $4,307,606$ & $4,307,606$ \\
\hline$R^{2}$ & 0.35 & 0.35 & 0.36 & 0.35 & 0.36 & 0.64 \\
\hline
\end{tabular}

Robust standard errors in square brackets

$* * * p<0.01, * * p<0.05, * p<0.10$

\section{Conclusion}

It is now widely accepted that producing and exporting higher quality products is essential for economic growth and export competitiveness. Hence, there is now a large body of literature geared towards unbundling the drivers of cross-country and industry differences in product quality. While prior studies largely focused on economic factors, more recent studies, although few, have begun to examine the role of institutional quality as a driver of product-quality upgrading. However, this nascent literature focuses primarily on the role of formal contracting institutions. We extend this literature by examining the role of trust, as a measure of informal contracting institution. Using industry-level data spanning 1995-2014, we identified the effect of trust on product quality following the generalized difference-in-difference method developed by Rajan and Zingales (1998). 
We find that contract-intensive industries in trust-intensive societies experience a disproportionally increase in the production and export of higher-quality products compared to those industries in low-trusting societies. This result holds after controlling for conventional sources of comparative advantage and formal contracting institution. Hence, the result underscores the importance of trust, as an informal contracting institution, for improved economic performance such as product-quality upgrading. At a more granular level, our result shows that countries with higher trust levels have comparative advantage in industries that are more prone to contractual frictions and opportunistic behaviors even in the absence (presence) of strong (weak) formal institutions. This occurs because higher trust levels, as an informal contracting institution, substitutes formal contracting institutions where they are lacking and complements them where they are present through efficient contracting. For instance, Dearmon and Grier (2011) note that in high trusting societies, the need for extensive contracts and the probability of outcomes ending in expensive litigation would be reduced as deals might be sealed with as little as a handshake. Similarly, Knack and Keefer (1997, p. 1252), note that in societies characterized by high trust level, "written contracts" are less likely to be needed, and they do not have to specify every possible contingency. Such open contracts but with mutual assurance that parties would not exhibit opportunistic tendencies even when the opportunity arises and the financial benefits are enormous, enables the parties to respond flexibly to changing market conditions which should leave both parties better-off. Given these benefits associated with higher trust level, our results suggest the need to promote policies that foster generalized trust as evidenced in the literature on the drivers of generalized trust (e.g., Alesina and La Ferrara 2000; Bjørnskov 2007; Murtin et al. 2018).

Supplementary Information The online version contains supplementary material available at https://doi. org/10.1057/s41287-021-00486-x.

Funding Open Access funding enabled and organized by Projekt DEAL.

\section{Declarations}

Conflict of interest On behalf of all authors, the corresponding author states that there is no conflict of interest.

Open Access This article is licensed under a Creative Commons Attribution 4.0 International License, which permits use, sharing, adaptation, distribution and reproduction in any medium or format, as long as you give appropriate credit to the original author(s) and the source, provide a link to the Creative Commons licence, and indicate if changes were made. The images or other third party material in this article are included in the article's Creative Commons licence, unless indicated otherwise in a credit line to the material. If material is not included in the article's Creative Commons licence and your intended use is not permitted by statutory regulation or exceeds the permitted use, you will need to obtain permission directly from the copyright holder. To view a copy of this licence, visit http://creativecommons.org/licen ses/by/4.0/. 


\section{References}

Acharyya, R., and R.W. Jones. 2001. Export quality and income distribution in a small dependent economy. International Review of Economics \& Finance 10 (4): 337-351.

Akçomak, S., and B. ter Weel. 2009. Social capital, innovation and growth: Evidence from Europe. European Economic Review 53 (5): 544-567.

Alesina, A., and E. La Ferrara. 2000. The determinants of trust. Networking Paper \#7621.

Amiti, M., and A. Khandelwal. 2013. Import competition and quality upgrading. Review of Economics and Statistics 952: 476-490.

Ang, J., Y. Cheng, and Wu. Chaopeng. 2015. Trust, investment, and business contracting. Journal of Financial \& Quantitative Analysis 503: 569-595.

Anwar, S., and S. Sun. 2018. Foreign direct investment and export quality upgrading in China's manufacturing sector. International Review of Economics \& Finance 54: 289-298.

Arrow, K. 1970. The organization of economic activity: Issues pertinent to the choice of market versus non-market allocation. In Public expenditure and policy analysis, ed. R. Haveman and J. Margolis. Chicago: Markham.

Ashraf, Q., and O. Galor. 2011. Cultural diversity, geographical isolation, and the origin of the wealth of Nations. NBER Working Papers \#17640.

Bas, M., and S.-K. Strauss-Kahn. 2015. Input-trade liberalization, export prices and quality upgrading. Journal of International Economics 95 (2): 250-262.

Bjørnsko, C., and P.-G. Meòn. 2015. The productivity of trust. World Development 70: 317-331.

Bjørnskov, C. 2007. Determinants of generalized trust: A cross-country comparison. Public Choice 130 (1): $1-21$.

Bjørnskov, C. 2012. How does social trust affect economic growth? Southern Economic Journal 78 (4): 1346-1368.

Bottazzi, L., M. Da Rin, and T. Hellmann. 2016. The importance of trust for investment: Evidence from venture capital. Review of Financial Studies 29 (9): 2283-2318.

Brooks, E.L. 2006. Why don't firms export more? Product quality and Colombian plants. Journal of Development Economics 80 (1): 160-178.

Castellacci, F., and J. Natera. 2011. A new panel dataset for cross-country analyses of national systems and development. Innovation and Development 12: 205-226.

Ciani, A., and F. Bartoli. 2020. Export quality differentiation under credit constraints. World Economy 43: $1398-1433$.

Cowan, K., and A. Neut. 2007. Intermediate goods, institutions and output per worker. Working Papers Central Bank of Chile \#420.

Crino, R., and L. Ogliari. 2017. Financial imperfections, product quality, and international trade. Journal of International Economics 104: 63-84.

De Jong, G., and R. Woolthuis. 2008. The institutional arrangements of innovation: Antecedents and performance effects of trust in high-tech alliances. Industry \& Innovation 15 (1): 45-67.

Dearmon, J., and K. Grier. 2011. Trust and the accumulation of physical and human capital. European Journal of Political Economy 27 (3): 507-519.

Dyer, J., and W. Chu. 2003. The role of trustworthiness in reducing transaction costs and improving performance: Empirical evidence from the U.S., Japan, and Korea. Organization Science 141: $57-68$.

Essaji, A., and K. Fujiwara. 2012. Contracting institutions and product quality. Journal of Comparative Economics 40: 269-278.

Falkowski, J., D. Curzi, and A. Olper. 2019. Contracting institutions, agro-food trade, and product quality. Journal of Agricultural Economics 703: 749-770.

Fan, H., A. Li, and S. Yeaple. 2015. Trade liberalization, quality, and export prices. Review of Economics \& Statistics 97 (5): 1033-1051.

Fan, Z., S. Anwar, and S. Huang. 2018. Cultural diversity and export sophistication. International Review of Economics \& Finance 58: 508-522.

Faruq, H. 2011. How institutions affect export quality. Economic Systems 354: 586-606.

Faruq, H., and M. Webb. 2016. Does culture drive innovation and export quality? International Economic Journal 30 (1): 19-38.

Gambetta, D. 1988. Trust: Making and breaking cooperative relations. Oxford: Blackwell. 
Gaulier, G., and S. Zignago. 2010. BACI: International trade database at the product-level. CEPII Working Paper \#2010-23.

Gil, R., and G. Zanarone. 2017. Formal and informal contracting: Theory and evidence. Annual Review of Law \& Social Science 13: 141-159.

Guiso, L., P. Sapienza, and L. Zingales. 2004. The role of social capital in financial development. American Economic Review 94 (3): 526-556.

Guiso, L., P. Sapienza, and L. Zingales. 2009. Cultural biases in economic exchange. Quarterly Journal of Economics 1243: 1095-1131.

Hallak, J. C. (2006). Product quality and the direction of trade. Journal of International Economics 68(1): $238-265$.

Hallak, J., and P. Schott. 2011. Estimating cross-country differences in product quality. Quarterly Journal of Economics 126 (1): 417-474.

Harding, T., and B. Javoricik. 2012. FDI and export upgrading. Review of Economics and Statistics 94 (9): 964-980.

Hausmann, R., J. Hwang, and D. Rodrik. 2007. What you export matters. Journal of Economic Growth 121: 1-25.

Henn, C., C. Papageorgiou, and N. Spatafora. 2020. Export quality in advanced and developing economies: Evidence from a new dataset. IMF Economic Review 68: 421-451.

Hsu, P.-H., X. Tian, and Y. Xu. 2014. Financial development and innovation: Cross-country evidence. Journal of Financial Economics 112 (1): 116-135.

Huchet-Bourdon, M., C. Le Mouël, and M. Vijil. 2017. The relationship between trade openness and economic growth: Some new insights on the openness measurement issue. World Economy 41 (1): 59-76.

Hummels, D., and P.J. Klenow. 2005. The variety and quality of a nation's exports. American Economic Review 95 (3): 704-723.

Igan, D., A. Kutan, and A. Mirzae. 2016. Real effects of capital inflows in emerging markets. International Monetary Fund Working Paper \#16/235.

Khandelwal, A. 2010. The long and short (of) quality ladder. Review of Economic Studies 77: 1450-1476.

Khandelwal, A., P. Schott, and S. Wei. 2013. Trade liberalization and embedded institutional reform: Evidence from Chinese exporters. American Economic Review 1036: 2169-2195.

Knack, S., and P. Keefer. 1997. Does social capital have an economic payoff? A cross-country investigation. Quarterly Journal of Economics 1124: 1251-1288.

Kroszner, R., L. Laeven, and D. Klingebiel. 2007. Banking crises, financial dependence, and growth. Journal of Financial Economics 84: 187-228.

Levchenko, A. 2007. Institutional quality and international trade. Review of Economic Studies 743: $791-819$.

Lyons, B., and J. Mehta. 1997. Contracts, opportunism, and trust: Self-interest and social orientation. Cambridge Journal of Economics 212: 239-257.

Manova, K. 2013. Credit constraints, heterogeneous firms, and international trade. Review of Economic Studies 80: 711-744.

Manova, K., and Z. Yu. 2017. Multi-product firms and product quality. Journal of International Economics 109: 116-137.

Mccannon, B., C. Asaad, and M. Wilson. 2017. Contracts and trust: Complements or substitutes? Journal of Institutional Economics 145: 811-832.

Minondo, A. 2010. Exports' quality-adjusted productivity and economic growth. The Journal of International Trade \& Economic Development 19 (2): 257-287.

Mora, D. 2002. The role of comparative advantage in trade within industries. Review of World Economics 1382: 291-316.

Murtin, F., L. Fleischer, V. Siegerink, A. Aassve, Y. Algan, R. Boarini, S. González, et al. 2018. Trust and its determinants: Evidence from the trust lab experiment. OECD Working Papers \#2018/02.

Ndubuisi, G. 2020a. Contractual frictions and the patterns of trade: The role of generalized trust. Journal of International Trade \& Economic Development. https://doi.org/10.1080/09638199. 2020.1745259 .

Ndubuisi, G. 2020b. Trust and R\&D investments: Evidence from OECD countries. Journal of Institutional Economics 16: 809.

Ndubuisi, G., and S. Owusu. 2021. How important is GVC participation to export upgrading. The World Economy. https://onlinelibrary.wiley.com/doi/abs/10.1111/twec.13102. 
Nunn, N. 2007. Relationship-specificity, incomplete contracts, and the pattern of trade. Quarterly Journal of Economics 1222: 569-600.

Osei, D. 2019. Corrupt or corrupted networks? An empirical enquiry'. Unpublished PhD Thesis Maastricht University? https://cris.maastrichtuniversity.nl/en/publications/corrupt-or-corruptednetworks-an-empirical-enquiry.

Owusu, S. 2021. Powering structural transformation and productivity gains in Africa: The role of global value chains and resource endowments. UNU-MERIT Working Paper 2021-022.

Papageorgious, C., F. Perez-Sebastian, and N. Spatafora. 2019. Quality upgrading and export performance in the Asian growth Miracle. IMF Working Paper \#19/259.

Pevzner, M., F. Xie, and X. Xin. 2015. When firms talk, do investors listen? The role of trust in stock market reactions to corporate earnings announcements. Journal of Financial Economics 1171: 190-223.

Rajan, R., and L. Zingales. 1998. Financial dependence and growth. American Economic Review 883: 559-586.

Rauch, J. 1999. Networks versus markets in international trade. Journal of International Economics 481: 7-35.

Schott, P. 2004. Across-product versus within-product specialization in international trade. Quarterly Journal of Economics 1192: 647-678.

Seitz, M., and M. Watzinger. 2017. Contract enforcement and R\&D Investment. Research Policy 46 (1): 182-195.

Verhoogen, E.A. 2008. Trade, quality upgrading, and wage inequality in the Mexican manufacturing sector. The Quarterly Journal of Economics 123 (2): 489-530.

Zak, P., and S. Knack. 2001. Trust and growth. Economic Journal 111 (470): 295-321.

Zhu, S., and X. Fu. 2013. Drivers of export upgrading. World Development 51: 221-233.

Publisher's Note Springer Nature remains neutral with regard to jurisdictional claims in published maps and institutional affiliations. 